\title{
Beta-Arrestins and Receptor Signaling in the Vascular Endothelium
}

\author{
Claudia Lee ${ }^{1,+}(\mathbb{D})$, Gayathri Viswanathan ${ }^{2,+}$, Issac Choi ${ }^{2} \mathbb{D}$, Chanpreet Jassal ${ }^{3}$, Taylor Kohlmann ${ }^{4}$ and \\ Sudarshan Rajagopal 1,2,*(D)
}

1 Department of Biochemistry, School of Medicine, Duke University, Durham, NC 27710, USA; claudia.lee@duke.edu

2 Medical Center, Department of Medicine, Division of Cardiology, Duke University, Durham, NC 27710, USA; gayathri.viswanathan@duke.edu (G.V.); issac.choi@duke.edu (I.C.)

3 College of Arts and Sciences, The University of North Carolina at Chapel Hill, Chapel Hill, NC 27599, USA; cjassal@live.unc.edu

4 Trinity College of Arts and Sciences, Duke University, Durham, NC 27708, USA; taylor.kohlmann@duke.edu

* Correspondence: sudarshan.rajagopal@duke.edu

+ These authors contributed equally to this work.

Citation: Lee, C.; Viswanathan, G.; Choi, I.; Jassal, C.; Kohlmann, T.; Rajagopal, S. Beta-Arrestins and Receptor Signaling in the Vascular Endothelium. Biomolecules 2021, 11, 9. https://dx.doi.org/10.3390/ biom11010009

Received: 28 November 2020 Accepted: 19 December 2020 Published: 23 December 2020

Publisher's Note: MDPI stays neutral with regard to jurisdictional claims in published maps and institutional affiliations.

Copyright: $\odot 2020$ by the authors. Licensee MDPI, Basel, Switzerland. This article is an open access article distributed under the terms and conditions of the Creative Commons Attribution (CC BY) license (https:/ / creativecommons.org/ licenses/by/4.0/).

\begin{abstract}
The vascular endothelium is the innermost layer of blood vessels and is a key regulator of vascular tone. Endothelial function is controlled by receptor signaling through $\mathrm{G}$ protein-coupled receptors, receptor tyrosine kinases and receptor serine-threonine kinases. The $\beta$-arrestins, multifunctional adapter proteins, have the potential to regulate all of these receptor families, although it is unclear as to whether they serve to integrate signaling across all of these different axes. Notably, the $\beta$-arrestins have been shown to regulate signaling by a number of receptors important in endothelial function, such as chemokine receptors and receptors for vasoactive substances such as angiotensin II, endothelin- 1 and prostaglandins. $\beta$-arrestin-mediated signaling pathways have been shown to play central roles in pathways that control vasodilation, cell proliferation, migration, and immune function. At this time, the physiological impact of this signaling has not been studied in detail, but a deeper understanding of it could lead to the development of novel therapies for the treatment of vascular disease.
\end{abstract}

Keywords: beta-arrestin; $G$ protein-coupled receptor; chemokine receptors; receptor tyrosine kinases; receptor serine-threonine kinases; vascular endothelial growth factor receptor (VEGFR); type II bone morphogenetic protein receptor (BMPR-II)

\section{The Vascular Endothelium}

Endothelial cells are a key modulator for vascular homeostasis. Comprising the innermost layer within blood vessels, these cells act not only as a barrier between tissue and blood moieties, but also a regulator of vascular tone based off of physical and chemical signaling inputs from the environment [1,2]. A major component of vascular tone regulation relies on nitric oxide (NO) based pathways in which diffusion of $\mathrm{NO}$ to vascular smooth muscle cells, leads to cGMP production leading to vasodilation [1]. This production of NO by endothelial NO synthase (eNOS) is regulated via several signals such as shear stress, bradykinin, vascular endothelial growth factor (VEGF) during hypoxia, and serotonin from platelet aggregation [1]. Other NO-independent modulators of vascular tone include prostacyclin, as well as vasoconstrictor substances such as endothelin-1 (ET-1), vascoconstrictor prostanoids, and angiotensin II (AngII).

In the normal vasculature, NO maintains the vascular wall in a dormant state through inhibition of inflammation, cell proliferation, and thrombosis. This NO-dominant phenotype is believed to maintained via laminar shear stress and is assisted via S-nitrosylation of cysteine residues in proteins such as NFKB and other cell cycle proteins [3]. Dysregulation 
of endothelial cells is typically marked by switch from a NO-dominant silencing of cellular processes, to redox-based signaling. In this switch, reactive oxygen species (ROS) lead to the generation of hydrogen peroxide (generated by superoxide dismutase). The peroxide, similar to NO, can spread through the cell and alter proteins via their cysteine groups. Doing so switches endothelial cells to a more a proliferative, proinflammatory, and prothrombotic state [3].This state is further exacerbated by the increased expression of specific chemokines and chemokine receptors [4]. The resulting changes are thought to contribute to several vascular diseases including atherosclerosis, hypertension, cardiac failure, as well as microvascular dysfunction in diabetes [2,3].

A central component to endothelial function is the receptors which respond to the large variety of environmental signals such as hormones, other cells within the vasculature (i.e smooth muscle cells), neurotransmitters, pericytes, cytokines and oxygen tension. These include but are not limited to G protein-coupled receptors (GPCRs), receptor tyrosine kinases (RTKs), and receptor serine-threonine kinases (RS/TKs). Regulating their downstream signaling, $\beta$-arrestins have emerged as a crucial effector for several of these receptors.

In this review article, we will focus on the roles of $\beta$-arrestin as a key partner in endothelial cell mediated signaling and function. We will summarize recent findings of major signaling pathways mediated by $\beta$-arrestin within chemokine receptors, as well as other pertinent GPCRs, RTKs and RS/TKs. Furthermore, we will discuss the impact of these on vascular endothelial cell function and their application to potential therapeutics for vascular disease.

\section{2. $\beta$-Arrestins as a Common Signaling Node for Transmembrane Receptors}

The $\beta$-arrestins ( $\beta$-arrestin1 and 2 ) are intracellular adapter proteins best known for their regulation of GPCR signaling and can perform a wide array of functions in the cell (Figure 1) [5]. With 78\% sequence homology [6], the two $\beta$-arrestin isoforms have highly conserved structures consisting of two domains that pivot on an inter-domain hinge $[7,8]$.They are predominantly found in the cytoplasm, while $\beta$-arrestin 1 can also be found in the nucleus due to its nuclear localization signal [9]. Originally discovered to inhibit or "arrest" GPCR $\beta$-arrestins are now understood to have a complex role in regulated to varied array of cellular functions [10]. As with many other proteins, post translational modifications play a crucial role in dictating signaling and trafficking of $\beta$-arrestins. Both isoforms are constitutively phosphorylated (Ser412 for $\beta$-arrestin1, Ser361 and Thr383 for $\beta$-arrestin2) with dephosphorylation of the two $\beta$-arrestins controlling differential trafficking, desensitization kinetics, and recycling of receptors [11]. $\beta$-arrestin ubiquitination has been shown to result in sustained $\beta$-arrestin-GPCR interaction, prolonging MAP kinase (MAPK) activity [12]. $\beta$-arrestins also undergo various other post-translational modifications such as S-nitrosylation [13]. However, it is unclear as to how these modifications affect their signaling and functionality.

Though $\beta$-arrestins are classically understood to be a part of the machinery required for GPCR trafficking, it is now appreciated that they also act as signal transducers and transactivators for GPCRs and RTKs (Figure 1) [14]. After GPCR activation by a ligand, the receptor is phosphorylated, typically via $G$ protein Receptor Kinases (GRKs), leading to $\beta$-arrestin recruitment $[10,15-17]$. Recruited $\beta$-arrestins can act as a scaffold that links the receptor and the machinery for internalization via clathrin and AP2 (Figure 1) $[18,19]$. Though some GPCRs do not require $\beta$-arrestin for their internalization, it has been shown that they do require them for recycling [20]. In addition to sterically inhibiting $G$ proteins interactions within active receptors, $\beta$-arrestins also have the capability to initiate distinct signaling patterns [21]. $\beta$-arrestins have been shown to scaffold Raf-1, MEK1, and ERK (Figure 1) [22]. $\beta$-arrestins have also been shown to modulate ubiquitin dependent signaling by acting as an adaptor for E3 Ubiquitin ligase [23]. Counterintuitively, $\beta$-arrestins have also been shown to promote endosomal G protein signaling [24], specifically by the parathyroid hormone receptor [25] and the V2 Vasopressin receptor [26]. Nuclear $\beta$-arrestin1 is also 
able to directly influence epigenetic modifications by interacting with histone acetylases and deacetylases, influencing chromatin structures [26-28].

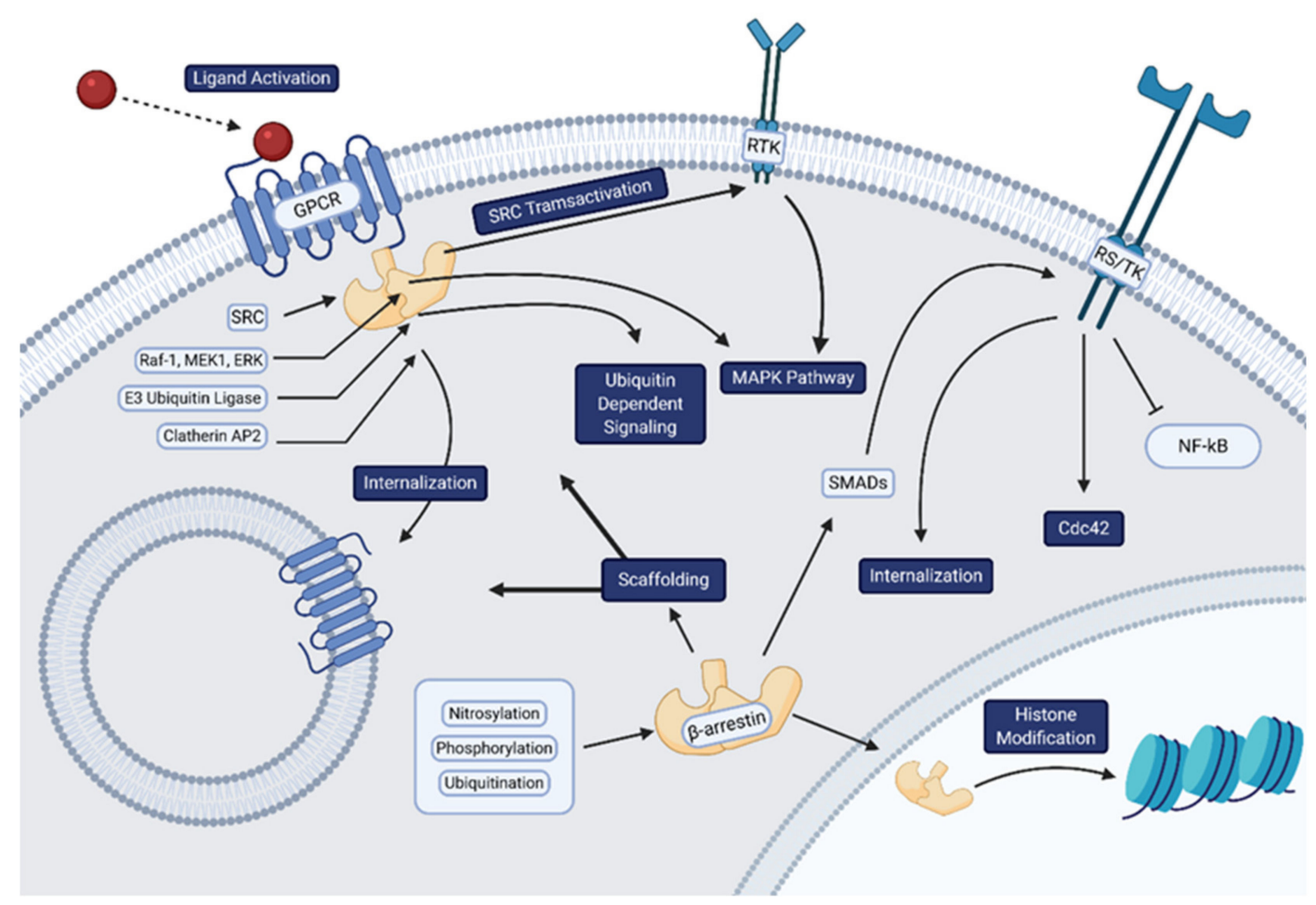

Figure 1. Overview of $\beta$-arrestin-mediated signaling. $\beta$-arrestins orchestrate a variety of cellular processes in addition to their originally discovered function of "arresting" GPCR signaling. These direct effects on membrane receptors such as internalization of GPCRs and transactivation of RTK and RS/TKs. $\beta$-arrestins can also promote their own signaling via scaffolding of several proteins (i.e MAPKs, Src, and clathrin), undergo various modifications such as ubiquitination, and influence epigenetic modifications. Created with BioRender.com.

An additional level of complexity in $\beta$-arrestin signaling stems from the function divergence of the two $\beta$-arrestin isoforms [29]. In some cases, one isoform predominates certain downstream signaling events. For example, $\beta$-arrestin2 at the CXC Chemokine Receptor 4 and Atypical Chemokine Receptor 3 (ACKR3), predominantly mediates ERK activation and CCL12 accumulation respectively [30,31]. In other cases, these isoforms can have reciprocal effects on the same target. Reduction of $\beta$-arrestin 2 leads to decreased ERK activation at the Angiotensin II type I receptor (AT1R), whereas knockdown of $\beta$-arrestin1 augments ERK activation [32]. $\beta$-arrestin2 plays a predominant. The differential signaling between $\beta$-arrestin isoforms have also been noted in to play roles in the vasculature and disease. Mouse models of myocardial infarction have shown $\beta$-arrestin 2 to offer protective effects via inflammation suppression under the $\beta 2 A R$ whereas $\beta$-arrestin1 negatively effects recovery $[33,34]$. In vascular smooth muscle cells, $\beta$-arrestin 2 signaling under the AT1R receptor leads to increased hypertrophy and hyperplasia in comparison to $\beta$-arrestin1 which decreases these effects [35]. $\beta$-arrestin2 in vascular endothelial cells and platelets.

Studies have implicated $\beta$-arrestins in endothelial and vascular function. For example, $\beta$-arrestin are reported to interact with caveolin-1, an abundant membrane protein in endothelial known present within caveolae, influence several endothelial cell functions, such as a membrane protein endocytosis of GPCRs and modulation of intracellular signaling events, extracellular matrix organization, and mechanotransduction [36]. The $\beta$-arrestincaveolin complex is suggested to modulate NO production pathways in response to mechanotransduction via phosphorylation of Akt and eNOS [37]. $\beta$-arrestin knockout mice have been displayed to lead to disfunction in eNOS activity via GPCR kinase interactor 1 (GIT1) in sinusoidal endothelial cells leading to increased portal hypertension upon liver in- 
jury [38]. We will further discuss the specific roles $\beta$-arrestin plays in downstream signaling events under select receptors in the following sections. As highlighted before, we would like to emphasize these receptors often have multiple aspects of signaling, such as the heterotrimeric G proteins with many GPCRs, and the unaddressed influences of these factors are often a caveat of $\beta$-arrestin signaling studies.

\section{3. $\beta$-Arrestin-Mediated GPCR Signaling in the Endothelium}

In addition to producing a broad range of chemokines in response to proinflammatory stimuli, endothelial cells also express a variety of chemokine receptors [4]. Chemokines are organized into four subgroups via the arrangement of the first two of four conserved cysteine residues within the N-terminus (CC, CXC, CX3C, and C) [39]. Increased expression of these chemokines and chemokine receptors in response to various factors such as hypoxia, toxins, and shear stress play a major role in endothelial cell physiology and dysfunction. The accumulation of chemokines and their receptors often lead to proangiogenic and proinflammatory signals, contributing to diseased states such as cancer, atherosclerosis, pulmonary arterial hypertension $(\mathrm{PAH})$, as well as autoimmune diseases $[3,4]$. $\beta$-arrestins also regulate signaling of receptors for vasoactive mediators, such as angiotensin II (AngII), endothelin-1 (ET-1) and prostaglandins. $\beta$-arrestins play central roles in regulating their signaling; for example, a number of GPCRs have been shown to activate eNOS, a key regulator of endothelial function, via $\beta$-arrestin2 [29]. We review some of the data focused on chemokine receptors and other GPCRs below (summarized in Table 1).

Table 1. Summary of $\beta$-arrestin-mediated signaling at selected GPCRs in endothelial cells.

\begin{tabular}{|c|c|c|c|}
\hline GPCR & $\beta$-Arrestin Modulated Signaling Activity & $\beta$-Arrestin Modulated Functional Response & Reference \\
\hline CXCR3 & Recruited to CXCR3 without ligand & Unclear & [35] \\
\hline CXCR4 & Receptor internalization, ERK activation & $\begin{array}{l}\text { Provides protective effects during } \\
\text { endothelial barrier impairment when } \\
\text { heterodimerized with PAR1 }\end{array}$ & {$[40,41]$} \\
\hline ACKR3 & ERK activation, Akt activation & $\begin{array}{l}\text { Angiogenesis, } \mathrm{Ca} 2+\text { mobilization, } \\
\text { leukocyte extravasation }\end{array}$ & {$[33,34,42-44]$} \\
\hline AT1R & ERK activation, Akt activation, Src recruitment & Proliferation of VSMCs & {$[45,46]$} \\
\hline APJ & Receptor internalization & Hypertrophy & [47] \\
\hline$\beta 2 A R$ & $\begin{array}{l}\text { ERK activation, Src recruitment, VE-cadherin } \\
\text { recruitment, p120-catenin recruitment }\end{array}$ & $\begin{array}{l}\text { Proliferation, permeability of the } \\
\text { endothelial cell barrier }\end{array}$ & {$[21,48,49]$} \\
\hline S1P1R & Receptor internalization & ERK activation, endothelial cell survival & {$[50,51]$} \\
\hline PAR1 & MAPK signaling & $\begin{array}{c}\text { Enhances tube-like capillary formation, migration, } \\
\text { TEER, and reduces permeability in } \\
\text { microvasculature endothelial cells }\end{array}$ & [52] \\
\hline ETR & Akt activation, NFKB activation, $\beta$-catenin signaling & $\begin{array}{l}\text { EGFR transactivation, suppressed ERK1/2 } \\
\text { phosphorylation, proliferation }\end{array}$ & [53-57] \\
\hline FP & $\begin{array}{c}\text { Recruit } \beta \text {-arrestin to AT1R in VSMC, ERK1/2 } \\
\text { activation }\end{array}$ & Unclear & [58] \\
\hline EP4 & PI3K/Akt activation, ERK activation, JNK activation & cell proliferation and migration & {$[59,60]$} \\
\hline
\end{tabular}

\subsection{C-X-C Chemokine Receptor Type 3}

Within endothelial cells, C-X-C chemokine receptor type 3 (CXCR3) serves as a prime regulator for pro-angiogenic and anti-angiogenic signals. CXCR3 is expressed as 3 reported splice variants (CXCR3A, CXCR3B, and CXCR3Alt) and primarily binds to the ligands CXCL4, CXCL9, CXCL10, CXCL11. CXCR3 activation by CXCL10 promotes CAMP production and protein kinase a (PKA) activation to inhibit VEGF-mediated endothelial tube formation [30]. CXCL10 also promotes p38/FAK signaling to induce migration as well as angiostatic activity via p38 [31,32]. Like most GPCRs, CXCR3 can signal via both $G$ protein and $\beta$-arrestin pathways [33]. Several studies have demonstrated changes in $\beta$-arrestin signaling downstream between the splice variants, as well as between the different chemokine ligands at the predominant receptor isoform (CXCR3A) [34,35]. CXCR3B is primarily 
expressed on microvascular endothelial cells and is found to be more "arrestin-biased" than CXCR3A given $\beta$-arrestin is preferentially recruited in absence of chemokines $[34,35]$. In comparison to CXCR3A, which utilizes GRK2/3 and GRK5/ 6 to mediate $\beta$-arrestin2 recruitment, CXCR3B utilizes GRK2/3 [34]. CXCR3B activation via CXCL10 and CXCL4 results in antiproliferative and antimigratory response compared to CXCR3A within microvascular endothelial cells [36]. Although $\beta$-arrestin is previously reported to have a role in endothelial cell functionality via the FAK and MAPK pathways under other receptors, it is unclear whether this occurs downstream of activated endothelial cell CXCR3 as well [37].

\subsection{C-X-C Chemokine Receptor Type 4}

C-X-C chemokine receptor type 4 (CXCR4) has long been implicated in promotion of angiogenesis through its primary cognate ligand, CXCL12 [38,61,62]. CXCR4 activation induces a variety of secondary effector signaling such as MAPK/ERK, phosphoinositide 3-kinase (PI3K)/Akt, and Wnt/ $\beta$-catenin pathways [61,63]. PI3K/Akt activation by CXCR4 in particular has been associated with increased expression of the pro-angiogenic factor VEGF [61,62]. While G proteins have been reported to promote many of CXCR4 downstream signaling functions, $\beta$-arrestin have been reported as a primarily negative regulator for CXCR4. Upon stimulation, CXCR4 is phosphorylated by various kinases, including GRK2, GRK3, GRK5, and GRK6. Phosphorylation at these key sites, two of which are Ser346 and 347, lead to $\beta$-arrestin recruitment and subsequent receptor desensitization and internalization [64,65]. Intriguingly, differential phosphorylation of CXCR4 in HEK293 cells by GRKs have been suggested to promote recruitment of particular $\beta$-arrestin isoforms and as a result, lead to differential downstream signaling [65]. GRK2, GRK6 phosphorylation of CXCR4 in HEK293 cells is associated with $\beta$-arrestin2 recruitment and negative regulation of calcium via receptor desensitization occurs primarily via, whereas GRK3, GRK6 phosphorylation is associated with $\beta$-arrestin1 positive regulation of ERK1/2 activation [65]. $\beta$-arrestin2 phosphorylation via ERK1/2 has also been shown to increase the intracellular distribution of the receptor, ultimately leading to decreased CXCR4 signaling [66]. In addition, endocytosis has been shown to be required for Akt activation by CXCR4, however it is unclear whether $\beta$-arrestins have a role in this process [62]. Heterodimerization of CXCR4 can impact $\beta$-arrestin signaling in other receptors within endothelial cells. CXCR4 interaction with protease-activated receptor 1 (PAR1) in human primary pulmonary endothelial cells reduces $\beta$-arrestin 1 signaling to promote protective effects during endothelial barrier impairment from thrombin $[40,41]$.

\subsection{Atyptical Chemokine Receptor 3}

Atypical chemokine receptor 3 (ACKR3, also known as CXCR7 or RDC-1) is coexpressed with CXCR4 in diverse cell types. These include vascular smooth muscle cell (VSMCs) [67] and vascular endothelial cells [68]. ACKR3 is thought to signal primarily through $\beta$-arrestin pathways, though underlying mechanisms are relatively unclear. ACKR3 is known to be phosphorylated via GRK2 to promote receptor endocytosis, however it is unknown which sites in particular are phosphorylated to promote $\beta$-arrestin recruitment [69,70]. ACKR3 activates ERKs or Akt [33,34,42], however, other data has suggested that this signaling may not depend on $\beta$-arrestins and is linked to signaling through other effectors that are sensitive to receptor phosphorylation [69,71]. CXCL12-stimulated ACKR3 acts as a functional receptor to activate Akt for angiogenesis in HUVECs [72]. During inflammatory conditions, both leukocytes and endothelial cells increase ACKR3 expression [73]. ACKR3 is also prominently expressed in a wide range of tumors both within the tumor cells and by cells of the tumor vasculature [74]. After stimulation with a small molecule ligand CCX771, ACKR3 has been shown to promote $\beta$-arrestin2-mediated signaling resulting in transendothelial migration of tumor cells. However, unlike other chemokine receptors, this occurred in the absence of classical GPCR-associated Ca2+ mobilization [43]. In addition, ACKR3 is induced in brain microvascular endothelial cells 
during experimental inflammatory conditions, such as permanent middle cerebral artery occlusion and experimental autoimmune encephalomyelitis (EAE) and promotes leukocyte extravasation by enhancing leukocyte adhesion to the endothelial surface [44].

\subsection{The Angiotensin II Type 1 Receptor}

The angiotensin II type 1 receptor (AT1R) is important in the regulation of vascular tone, and in proliferation and chemotaxis of vascular smooth muscle cells (VSMCs) [45]. Stimulation with AngII, leads to signaling mediated by both $G$ protein and $\beta$-arrestins [45]. $\beta$-arrestin2 mediates the pathway responsible for late and prolonged ERK activation, which is important in promotion of cell survival pathways, such as Akt phosphorylation, and in the proliferation of VSMCs by regulating processes such as DNA synthesis [45,46]. This same pathway can be activated in the absence of $G$ protein signaling by mechanical stress [46]. Specifically, mechanical stress causes the AT1R to enter an active conformation, in which it undergoes phosphorylation by GRK5 and GRK6, recruiting $\beta$-arrestin to the receptor [46]. Notably, double electron-electron resonance spectroscopy has indicated that when mediating $\beta$-arrestin-biased signaling, the AT1R is stabilized in a distinctly different conformation than when stimulated by AngII or G protein-biased ligands [75]. $\beta$-arrestin recruitment to the AT1R facilitates recruitment of factors such as Src kinase, which phosphorylates EGFR's Tyr-845, and heparin-binding EGF to the receptor, allowing for EGFR transactivation, which facilitates ERK activation [45].

\subsection{The Apelin Receptor}

The apelin receptor (APJ) is chiefly found in the endocardium of the heart and the endothelium of the vasculature [76]. It is important in the mediation of migration and proliferation necessary for cardiovascular development as well as in the regulation of vascular tone. Specifically, APJ is important in NO-dependent and -independent vasodilatation to diminish vasoconstriction induced by AngII via the AT1R [47,76]. APJ binds a number of endogenous ligands, including apelin (and its derivatives) and the peptide Elabela/Toddler which commonly exert a $G$ protein bias [47]. Lack of vasodilatation when APJ was stimulated with a synthetic G protein biased ligand, apelin-17, suggests that $\beta$ arrestin may mediate the pathways responsible for counteracting vasoconstriction elicited by AngII [47]. Additionally, in response to mechanical stress, APJ recruits $\beta$-arrestin, but not $\mathrm{G}$ proteins, resulting in hypertrophy and receptor internalization [47]. The residues Phe 257, Trp 263, and Ser 348 in the human APJ receptor have been determined necessary for this $G$ protein-independent signaling via GRKs and $\beta$-arrestin [47].

\section{6. $\beta 2$ Adrenergic Receptor}

The $\beta 2$-adrenergic receptor ( $\beta 2 A R$ ) is important in the regulation of vascular tone [77]. ${ }^{19} \mathrm{~F}-\mathrm{NMR}$ examining the active conformation of the $\beta 2 \mathrm{AR}$ has shown that full agonists (such as isoproterenol) produce significant changes in the conformations of helices VI and VII, while $\beta$-arrestin-biased agonists (such as carvedilol and isoetharine) only impact helix VII; this suggests a structural basis for a separate, but parallel, nature of $G$ protein and $\beta$-arrestin signaling at the $\beta 2 A R$ [78]. Additionally, earlier studies have suggested that differential phosphorylation at the $\beta 2 A R$ by GRK2 and GRK6, similar to that of CXCR4, lead to distinct $\beta$-arrestin signaling where GRK2 primarily influenced receptor internalization and GRK6 sites influence $\beta$-arrestin mediated ERK activation [79]. When the receptor is activated, $\beta$-arrestin1 is recruited to the $\beta 2 \mathrm{AR}$ [48], where it is dephosphorylated at Ser 412; the SH3 domain of c-Src-Src kinase dephosphorylated at Tyr 530 - associates with the Pro-X$X$-Pro consensus sequence found in the $\mathrm{N}$-terminal region of $\beta$-arrestin1; this complex facilitates Ras-dependent ERK phosphorylation and activation [21]. The resultant ERK pathway is important in cell survival, proliferation, and differentiation [48]. $\beta$-arrestinmediated Src recruitment at the $\beta 2 \mathrm{AR}$ is also important in the brain endothelium, where Src phosphorylates cortactin, thereby facilitating fixation of meningococcus bacteria to endothelial cells [49]. Furthermore, $\beta$-arrestins are also involved in recruiting VE-cadherin 
and p120-catenin, which play a role in increasing the permeability of the endothelial cell barrier, aiding in meningococcal crossing of the blood-brain barrier [49]. However, a study using $\beta$-arrestin $1 / 2$ knockout cells and Gs knockout cells indicated that, following $\beta 2 A R$ activation with isoproterenol and carvedilol, ERK phosphorylation was observed in cells lacking $\beta$-arrestin1 and 2 but not in cells lacking Gs, suggesting that $G$ proteins, but not $\beta$-arrestin, are necessary in this pathway [48]. Addition of $\beta$-arrestin to $\beta$-arrestin $1 / 2$ knockout cells did produce stronger and longer-lasting ERK signaling, until excessive $\beta$-arrestin decreased ERK signaling [48]. This suggests that $\beta$-arrestins are functionally important in $\beta 2 A R$ signaling as scaffolds, whereas $G$ proteins may be necessary for the initiation of ERK activation [48].

\subsection{Sphingosine-1-Phosphate Receptor 1}

Sphingosine-1-phosphate receptor 1, also known as S1P1R is a high affinity receptor for the bioactive lipid (2S,3R,4E)-Sphingosine 1-phosphate [80,81]. Although the S1P1R expression is very abundant in endothelial cells, transcripts related to S1P1R are also detected at lower levels in vascular smooth muscle cells, fibroblasts, melanocytes, cells of epithelioid origin, brain [82], alveolar macrophages [83], cardiovascular tissues [84], natural killer cells and T cells [85]. S1P1 receptor is a G-protein coupled receptor which promotes signaling through Gai/o proteins [86,87]. Endocytosis of G-protein-coupled receptor signal complexes is required for activation of ERK1/2. $\beta$-arrestin1 is recruited to ligand-bound S1P1R phosphorylated by GRK2. $\beta$-arrestin1 binds to Clathrin and activates Clathrin-mediated endocytosis [50]. Activation of ERK1/2 was shown to mediate (2S,3R,4E)-Sphingosine 1-phosphate-induced endothelial cell survival [51]. Prolonged desensitization of S1P1R via receptor phosphorylation, internalization, and degradation has been associated with endothelial cell damage and decreased survival [88-90].

\subsection{Protease-Activated Receptor 1}

Protease-Activated Receptor 1 (PAR1) contains a tethered ligand that is exposed after cleavage by thrombin and can increase vascular permeability [91]. Activated protein C (APC) also cleaves PAR1, resulting in exposure of a different tethered ligand with a distinct biological response [92-94]. Other groups have shown that APC binding to its receptor endothelial protein $C$ receptor results in GRK5 recruitment to PAR1, which is crucial for promoting $\beta$-arrestin2 biased signaling by both APC and thrombin [95]. Despite their opposing effects, both APC and thrombin interact with PAR1 on endothelial cells [96]. A recent study demonstrated that APC activates $\beta$-arrestin- 2 , leading to PAR1- $\beta$ arrestin-2-MAPK 42/44 signaling that has a protective effect on endothelial function via PDGF- $\beta$ [52]. APC enhanced tube-like capillary formation, migration, and transepithelial electrical resistance (TEER) while reducing permeability in bovine brain microvasculature endothelial cells [52]. In contrast, thrombin decreased expression of occludin, claudin-5, and ZO-1 and rapidly induced vascular permeability. Thrombin also reduced TEER rapidly while APC enhanced TEER more slowly. Consistent with bias between these two agonists, thrombin enhanced paracellular permeability while APC reduced paracellular permeability. Notably, the $\beta$-arrestin 2 knockdown reduced while $\beta$-arrestin 2 overexpression increased APC-induced tube-like capillary formation in HUVECs. The knockdown of $\beta$-arrestin2 also reduced migration, reduced TEER, and increased permeability in HUVECs [52].

\subsection{Endothelin Receptors}

Endothelin-1 (ET-1) was originally extracted from aortic endothelial cells and was identified as a strong vasoconstrictor [97] and to play an important role in the cardiovascular system. ET-1 and its related peptides, ET-2 and ET-3, exerts their biological effects through two types of receptors, type $A\left(E T_{A} R\right)$ and $B\left(E T_{B} R\right)$ [98]. $E_{A} R$ is expressed primarily in smooth muscle cells and exerts vasoconstrictive and cardiotonic effects, while the $E_{B} R$ is expressed primarily in endothelial cells and seems to antagonize $E_{A} R$ signaling. ET-1 receptors are phosphorylated primarily via GRK2, however phosphorylation is not 
an absolute requirement for $\beta$-arrestin binding, desensitization, or internalization [99]. The knockdown of $\beta$-arrestin1 or $\beta$-arrestin 2 in human kidney embryonic 293 cells resulted in enhanced ERK $1 / 2$ phosphorylation in response to ET-1. A study shows that $\beta$-arrestins and EGFR transactivation are involved in $\mathrm{ET}_{\mathrm{A} / \mathrm{B}} \mathrm{R}$ signaling [57]. Epidermal growth factor receptors(EGFRs) were internalized in response to ET-1, while pretreatment with AG1478 (an EGFR antagonist) suppressed ERK1/2 phosphorylation in response to ET-1 [57]. Notably, $\beta$-arrestin1 has been shown to link $\mathrm{ET}_{\mathrm{A}} \mathrm{R}$ to $\beta$-catenin signaling $[53,54]$, Akt activation [55], and NFKB activation [56], consistent with it playing a central role in it promoting its pro-proliferative signaling.

\subsection{Prostaglandin Receptors}

GPCRs can also form functional homo- and heterodimers that act as distinct signaling hubs for cellular signal integration [100]. The AT1R and the prostaglandin F2 $\alpha$ (PGF2 $\alpha$ ) receptor $(\mathrm{FP})$, both of which are important in the control of smooth muscle contractility, have been shown to form functional heterodimeric complexes in HEK 293 and vascular smooth muscle cells [58]. Although FP does not normally recruit $\beta$-arrestin1/2 [58,97], as there are GPCRs that don't recruit $\beta$-arrestin [101], stimulation of FP can recruit $\beta$-arrestin to an AT1R partner in the context of a heterodimer in both HEK 293 and vascular smooth muscle cells (VSMC) where they are endogenously co-expressed [58]. When the AT1R was treated with an antagonist, it strongly potentiated ERK1/2 activation by FP. In contrast, treatment of FP with an antagonists did not have a significant effect on AngII-mediated ERK1/2 activation [58]. Deletion of several G $\alpha$ subunits significantly abrogated both AngII- and PGF2 $\alpha$-mediated $\beta$-arrestin1/ 2 recruitment which was in all cases restored by re-expression of $\mathrm{G} \alpha 11, \mathrm{G} \alpha 12$, or $\mathrm{G} \alpha 13$ but not always $\mathrm{G} \alpha \mathrm{q}$ [102]. AngII induced a rapid, robust, and sustained recruitment of $\beta$-arrestin $1 / 2$ to AT1R and, to a lesser extent, the heterodimer, as expected, since AT1R is a strong recruiter of both $\beta$-arrestin subtypes [102]. However, PGF2 $\alpha$ did not induce such recruitment to FP alone, although it did when the AT1R is present as a heterodimer [102]. Taken together, PGF2 $\alpha$ specifically recruits and signals through $\beta$-arrestin but only in the context of the AT1R/FP dimer, suggesting that this may be a new allosteric signaling entity. Notably, a prostaglandin E2 receptor 4 (EP4)- $\beta$-arrestin signaling complex has been well characterized whereby GRK and protein kinase A (PKA) phosphorylation of EP4 recruits $\beta$-arrestin1 to activate c-Src to initiate EGFR transactivation. Activation leads to subsequent downstream signaling through PI3K and Akt [103]. It was recently recognized that the EP2 receptor regulates $\beta$-arrestin signaling to initiate PI3K/Akt, ERK, and c-Jun N-terminal kinase (JNK) pathways, which are particularly important for cell proliferation and migration $[59,60]$.

\section{4. $\beta$-Arrestin Regulation of Receptor Tyrosine Kinases \\ 4.1. Vascular Endothelial Growth Factor Receptors}

Vascular endothelial growth factor receptors (VEGFRs) belong to the family of receptor tyrosine kinases and play a central role in endothelial function, including cell proliferation and survival, angiogenesis, and lymphangiogenesis [104]. VEGFRs are activated by several vascular endothelial growth factors (VEGF-A, VEGF-B and VEGF-C) $[105,106]$. $\beta$-arrestin2 has been shown to regulate VEGF-mediated control of endothelial permeability through the endocytosis of VE-cadherin [107]. Knockdown of $\beta$-arrestin1 inhibited VEGF-C-induced human lung microvascular endothelial cells (HMVEC-L) proliferation, migration, and angiogenesis [108]. Consistent with that, knockdown of $\beta$-arrestin1 reduced VEGFR3, $\mathrm{Akt}$, and endothelial nitric oxide synthase phosphorylation. This regulation was mediated by direct $\beta$-arrestin1 binding to the VEGFR3 kinase domain and resulted in decreased VEGFR3 internalization (Table 2) [108]. 
Table 2. Summary of $\beta$-arrestin-mediated signaling at selected RTKs and RS/TKs in endothelial cells.

\begin{tabular}{|c|c|c|c|}
\hline RTK or RS/TK & $\beta$-Arrestin Modulated Signaling Activity & $\beta$-Arrestin Modulated Functional Response & Reference \\
\hline VEGFR & $\begin{array}{l}\text { Akt activation, and endothelial nitric oxide } \\
\text { synthase phosphorylation, } \\
\text { VE-cadherin endocytosis }\end{array}$ & $\begin{array}{l}\text { HMVEC-L proliferation, migration, and } \\
\text { angiogenesis, cell permeability }\end{array}$ & {$[107,108]$} \\
\hline EGFR & $\begin{array}{c}\text { Src activation, matrix metalloproteinase, } \\
\text { heparin-binding EGF-like growth } \\
\text { factor (HB-EGF) }\end{array}$ & Anti-apoptotic and cardioprotective effects & {$[109,110]$} \\
\hline $\mathrm{T} \beta \mathrm{Rs}$ & $\begin{array}{l}\text { Clathrin-dependent internalization, } \\
\text { downregulates both Smad phosphorylation } \\
\text { and p38 phosphorylation }\end{array}$ & Inhibits NF- $\mathrm{kB}$ dependent cell migration & [111] \\
\hline BMPRs & Smad signaling & Angiogenesis, proliferation, and migration. & [112] \\
\hline
\end{tabular}

\subsection{Epidermal Growth Factor Receptor}

$\beta$-arrestins have been shown to exert antiapoptotic and cardioprotective effects through transactivation of epidermal growth factor (EGF) receptor (EGFR) via Src, matrix metalloproteinase, heparin-binding EGF-like growth factor (HB-EGF) [109]. $\beta$-arrestinmediated pathway uses the $\beta 1$-adrenergic receptor ( $\beta 1 \mathrm{AR})$ to transactivate the EGFR. $\beta$-adrenergic ligands that do not activate $G$ protein signaling (i.e., $\beta$-blockers) alprenolol (Alp) and carvedilol (Car) induce $\beta 1$ AR-mediated transactivation of the EGFR and downstream ERK activation (Table 2) [110].

\section{5. $\beta$-Arrestin Regulation of Receptor Serine-Threonine Kinases}

\subsection{Transforming Growth Factor- $\beta$ (TGF- $\beta$ ) Receptor}

The type III TGF $\beta$ receptor (T $\beta$ RIII or betaglycan) is a coreceptor expressed in endothelial-specific heteromeric complexes [111]. $\beta$-arrestin2 binds and mediates its clathrin-dependent internalization, which downregulates both Smad phosphorylation and Smad-independent p38 phosphorylation [111]. Studies have also shown that $\beta$-arrestin2 mediates T $\beta$ RIII-induced activation of Cdc42 and inhibits NF-kB -dependent cell migration [111]. Conversely, the interaction of $\beta$-arrestin 2 with endoglin, an endothelial-specific TGF $\beta$ coreceptor involved in angiogenesis and the homeostasis of vessel walls, is responsible for sequestering ERK in the cytoplasm, which prevents cell migration without affecting Smad-dependent signaling (Table 2) [111].

\subsection{Bone Morphogenetic Protein Receptors}

Bone morphogenic receptors (BMPRs) are members of the transforming growth factorsuperfamily and play a multifunctional role in aiding development that regulates cell proliferation, differentiation, and apoptosis in various tissue types [113]. The majority of ligands (BMP-2, BMP-4, BMP-6, BMP-7, GDF-5, and GDF-6) have high affinity for type I receptors, predominantly BMPRIA activin-like receptor kinase-3 (ALK3) or BMPRIB (ALK6), due to the formation of heteromeric receptor complexes [114]. Stimulation with these ligands induces angiogenesis, EC proliferation, and migration. BMPs have also been shown to play key roles in the inhibition of vascular SMCs, while enhancing the differentiation of these cells [113]. After BMP ligand induced heteromeric complex formation, type II receptor kinases phosphorylate the type I receptor, initiating intracellular signaling via activation of Smad proteins [113]. BMPRs can also initiate non-Smad signaling pathways involved in the pathogenesis of vascular diseases, such as MAPK, PI3K/Akt and protein kinase C (PKC) signaling pathways, and Rho-GTPases, which are potentiated by ALK6 through $\beta$-arrestin induced internalization [111]. A role for $\beta$-arrestin1 has been demonstrated in the regulation of BMPRII signaling through Smads and their transcriptional targets as reported in abstract for [112]; the manuscript describing these finding in detail is currently in preparation (S. Rajagopal, personal communication) (Table 2). 


\section{Potential for Targeting $\beta$-Arrestins and Endothelial Cells in Vascular Disease}

Endothelial dysfunction, characterized by an imbalance in signaling between endotheliumderived vasodilators (eg, $\mathrm{NO}$ and prostacyclin) and vasoconstrictors (eg, thromboxane A2, ET-1, and AngII), has been associated with many cardiovascular diseases [115]. Endothelial dysfunction can occurs in diseases of large vessels, such as atherosclerosis, and of small vessels, such as PAH [116]. Targeting $\beta$-arrestin-mediated signaling by these receptors are predicted to have a number of potential benefits.

\section{1. $C X C R 4$}

Several studies have cited CXCR4 signaling to be implicated in vascular diseases. Lung tissue and animal models for PAH have shown increased CXCR4 expression [117]. AMD3100, a known CXCR4 antagonist, attenuated pulmonary angiogenesis leading to prevention of hepatopulmonary syndrome (HPS) in mice [118]. Similarly CXCR4 knockdown models in HUVECs have shown potential to decrease angiogenesis suggesting abrogation of signaling within cancer tissues [63]. While no studies have directly shown $\beta$-arrestins to have therapeutic potential under CXCR4 signaling, its ability to inhibit CXCR4 signaling could lead to the development of novel therapies.

\section{2. $A C K R 3$}

ACKR3 does not result in activation of signaling pathways typical of $G$ proteins but does activate MAP kinases through $\beta$-arrestins. Injured coronary arteries from both humans and angioplasty wire injury mice exhibited endothelial ACKR3 expression. Conditional endothelial ACKR3 deletion promoted neointimal formation after endothelial injury and exacerbated heart functional impairment after myocardial infarction (MI). Both ACKR3 gene delivery via left ventricular injection and treatment with a CXCR7 agonist offered cardiac protection after MI [119]. ACKR3 is elevated in the endothelium of explanted human hypertensive lungs and circulating CXCL12 concentrations are significantly elevated in disease. ACKR3 inhibition by CCX771 or CCX773 blocked proliferation but not migration of human pulmonary microvascular endothelial cells in vitro. ACKR3 is the receptor through which endothelial cell regeneration and repair, and proliferation, is mediated, whereas signaling via CXCR4 is essential for chemotactic cell migration [110]. ACKR3 inhibitors will need to be tested in additional vascular disease models to see if targeting its signaling could be beneficial.

\section{3. $S 1 P 1 R$}

Current clinical molecules that have been developed to target S1P1R provide therapeutic benefits in autoimmune disorders given S1P1R's role in lymphocyte trafficking and endothelial cell function. Given the deleterious effects of prolonged $\beta$-arrestin mediated desensitization of S1P1R in endothelial cell survival which pose, a recent study developed a G-protein biased compound, SAR247799 to see if the damaging side effects of S1P1R desensitization could be selectively inhibited [88]. SAR247799 was found to potently activate protection pathways under the S1P1R without causing receptor desensitization. Additionally the ligand improved microvascular response in a pig model of coronary endothelial damage as well as preserved renal structure and function in a rat model of renal ischemia

\subsection{PAR1}

Activation of PAR1 by thrombin and APC leads to paradoxical functions where thrombin promotes cell death and barrier disruption, while APC promotes cell protection and barrier protection [52]. Currently, PAR1 is the target of anti-thrombins such as dabigatran, which is known to prevent PAR1 cleavage, activation, internalization, and $\beta$-arrestin recruitment in vitro and can be used for the treatment of acute ischemic stroke and for preventing recurrence [120]. More recent studies have suggested $\beta$-arrestin biased signaling via APC at PAR1 as a novel avenue for therapeutics for treatment of stroke with 
a reduced risk of excessive bleeding. In particular, a Lys191-193 Ala APC mutant was found to decrease anticoagulant activity by $>90 \%$ while retaining normal cell signaling while granting cardioprotection against ischemia [121]. Supporting this theory, a recent study found APC stimulated $\beta$-arrestin signaling at PAR1 provided protective effects in endothelial cells in mice after experiencing a stroke or high-fat diet induced obesity [52].

\subsection{Endothelin Receptors}

ET-1 is a strong vasoconstrictor that plays important roles in the pathogenesis and progression of cardiovascular remodeling. ET receptor antagonists (ERAs) are FDA-approved for the treatment of PAH by preventing vasoconstriction and abnormal smooth muscle cell proliferation [122]. Notably, the knockdown of $\beta$-arrestin1 or $\beta$-arrestin2 in human kidney embryonic 293 cells resulted in enhanced ERK1/2 phosphorylation and EGFR internalization in response to ET [110]. Pre-treatment with Ro318425 (a PKC inhibitor) or AG1478 (an EGFR antagonist) suppressed ERK1/2 phosphorylation in response to ET [57]. These findings suggest that both $G$ proteins and $\beta$-arrestins contribute to abnormal cellular proliferation in PAH, and that ERAs may have a role in the treatment of other forms of vascular disease.

\subsection{VEGFR}

VEGFR signaling a common target for tumor angiogenesis $[123,124]$. Breast cancer mouse models have shown targeting $\beta$-arrestin1 regulates induction of VEGF-A via hypoxia-induced factor- $1 \alpha$. Use of anti-angiogenic drug, thalidomide, or imatinib mesylate, both induced nuclear export of $\beta$-arrestin1 to prevent VEGF transcription and release, suggesting targeting $\beta$-arrestin 1 localization could be useful in inhibiting aberrant angiogenesis and metastasis [124].VEGFR3 was also recently found to be expressed in the endothelial tip cells during angiogenesis and in tumor vasculature $[125,126]$. VEGFRs are also implicated in PAH. In rodent models of PAH, the VEGFR2 inhibitor SU-5416 has been used in combination with chronic hypoxia to induce PAH [127]. Furthermore, endothelial cell-specific knockout of Vefgr3 in mice causes exacerbation of chronic hypoxia-induced PAH, suggesting a role for VEGFR3 signaling in endothelial cells in the pathogenesis of PAH [128]. Recent studies have also linked $\beta$-arrestin1 with VEGR3 regulation in PAH. Both $\beta$-arrestin1 and VEGFR3 are reduced in human PAH and deletion of $\beta$-arrestin1 led to worse PAH and abrogation of VEGFR3 signaling in mice exposed to hypoxia [108]. Therefore, promoting $\beta$-arrestin-mediated VEGFR2 and 3 signaling may be useful in the treatment of PAH.

\section{Conclusions}

Endothelial cell dysfunction is a hallmark of several vascular diseases. Over a decade of research has implicated chemokine and other receptor signaling in endothelial cell physiology through their effects on growth, migration, and immune function. In this review, we highlighted various ways in which $\beta$-arrestin modulates key aspects of endothelial cell function through their regulation of GPCRs, RTKs and RS/TKs. At this time there have only been limited studies on how $\beta$-arrestins can act as nodes for integrating signaling from these different signaling axes. With additional studies that focus on such cross-talk and on the physiological implications of this signaling, we may develop novel insights into how targeting $\beta$-arrestin-mediated receptor signaling in the vasculature can be useful as a therapeutic strategy in vascular disease.

Author Contributions: Conceptualization, C.L., G.V., S.R.; writing—original draft preparation, C.L., G.V., I.C., C.J., T.K.; writing-review and editing, C.L., S.R. All authors have read and agreed to the published version of the manuscript.

Funding: This research received no external funding.

Conflicts of Interest: The authors declare no conflict of interest. 


\section{References}

1. Schwartz, B.G.; Economides, C.; Mayeda, G.S.; Burstein, S.; A Kloner, R. The endothelial cell in health and disease: its function, dysfunction, measurement and therapy. Int. J. Impot. Res. 2009, 22, 77-90. [CrossRef] [PubMed]

2. Deanfield, J.E.; Halcox, J.P.; Rabelink, T.J. Endothelial Function and Dysfunction. Circulation 2007, 115, 1285-1295. [CrossRef] [PubMed]

3. Gimbrone, M.A., Jr.; García-Cardeña, G. Endothelial Cell Dysfunction and the Pathobiology of Atherosclerosis. Circ. Res. 2016, 118, 620-636. [CrossRef] [PubMed]

4. Speyer, C.L.; Ward, P.A. Role of Endothelial Chemokines and Their Receptors during Inflammation. J. Investig. Surg. 2011, 24, 18-27. [CrossRef]

5. Peterson, Y.K.; Luttrell, L.M. The Diverse Roles of Arrestin Scaffolds in G Protein-Coupled Receptor Signaling. Pharmacol. Rev. 2017, 69, 256-297. [CrossRef]

6. Attramadal, H.; Arriza, J.L.; Aoki, C.; Dawson, T.M.; Codina, J.; Kwatra, M.M.; Snyder, S.H.; Caron, M.G.; Lefkowitz, R.J. Beta-arrestin2, a novel member of the arrestin/beta-arrestin gene family. J. Biol. Chem. 1992, 267, 17882-17890.

7. Nobles, K.N.; Guan, Z.; Xiao, K.; Oas, T.G.; Lefkowitz, R.J. The Active Conformation of $\beta$-Arrestin1. J. Biol. Chem. 2007, 282, 21370-21381. [CrossRef]

8. Hanson, S.M.; Francis, D.J.; Vishnivetskiy, S.A.; Kolobova, E.A.; Hubbell, W.L.; Klug, C.S.; Gurevich, V.V. Differential interaction of spin-labeled arrestin with inactive and active phosphorhodopsin. Proc. Natl. Acad. Sci. 2006, 103, 4900-4905. [CrossRef]

9. Hoeppner, C.Z.; Cheng, N.; Ye, R.D. Identification of a Nuclear Localization Sequence in $\beta$-Arrestin-1 and Its Functional Implications. J. Biol. Chem. 2012, 287, 8932-8943. [CrossRef]

10. Lohse, M.J.; Benovic, J.L.; Codina, J.C.; Caron, M.G.; Lefkowitz, R.J. beta-Arrestin: a protein that regulates beta-adrenergic receptor function. Sci. 1990, 248, 1547-1550. [CrossRef]

11. Lin, F.T.; Krueger, K.M.; E Kendall, H.; Daaka, Y.; Fredericks, Z.L.; A Pitcher, J.; Lefkowitz, R.J. Clathrin-mediated endocytosis of the beta-adrenergic receptor is regulated by phosphorylation/dephosphorylation of beta-arrestin1. J. Biol. Chem. 1997, 272, 31051-31057. [CrossRef] [PubMed]

12. Shenoy, S.K.; Lefkowitz, R.J. Receptor-specific Ubiquitination of $\beta$-Arrestin Directs Assembly and Targeting of Seven-transmembrane Receptor Signalosomes. J. Biol. Chem. 2005, 280, 15315-15324. [CrossRef] [PubMed]

13. Ozawa, K.; Whalen, E.J.; Nelson, C.D.; Mu, Y.; Hess, D.T.; Lefkowitz, R.J.; Stamler, J.S. S-Nitrosylation of $\beta$-Arrestin Regulates $\beta$-Adrenergic Receptor Trafficking. Mol. Cell 2008, 31, 395-405. [CrossRef] [PubMed]

14. Dalle, S.; Imamura, T.; Rose, D.W.; Worrall, D.S.; Ugi, S.; Hupfeld, C.J.; Olefsky, J.M. Insulin induces heterologous desensitization of G-protein-coupled receptor and insulin-like growth factor I signaling by downregulating beta-arrestin-1. Mol. Cell. Biol. 2002, 22, 6272-6285. [CrossRef]

15. Benovic, J.L.; Kuhn, H.; Weyand, I.; Codina, J.; Caron, M.G.; Lefkowitz, R.J. Functional desensitization of the isolated betaadrenergic receptor by the beta-adrenergic receptor kinase: potential role of an analog of the retinal protein arrestin (48-kDa protein). Proc. Natl. Acad. Sci. 1987, 84, 8879-8882. [CrossRef]

16. Gurevich, V.V.; Gurevich, E.V. The new face of active receptor bound arrestin attracts new partners. Struct. 2003, 11, 1037-1042. [CrossRef]

17. Wilden, U. Duration and Amplitude of the Light-Induced cGMP Hydrolysis in Vertebrate Photoreceptors Are Regulated by Multiple Phosphorylation of Rhodopsin and by Arrestin Binding. Biochem. 1995, 34, 1446-1454. [CrossRef]

18. Iannolo, G.; E Salcini, A.; Gaidarov, I.; Goodman, O.B.; Baulida, J.; Carpenter, G.; Pelicci, P.G.; Di Fiore, P.P.; Keen, J.H. Mapping of the molecular determinants involved in the interaction between eps15 and AP-2. Cancer Res. 1997, 57, $240-245$.

19. Oakley, R.H.; Laporte, S.A.; Holt, J.A.; Barak, L.S.; Caron, M.G. Association of $\beta$-Arrestin with G Protein-coupled Receptors during Clathrin-mediated Endocytosis Dictates the Profile of Receptor Resensitization. J. Biol. Chem. 1999, $274,32248-32257$. [CrossRef]

20. Vines, C.M.; Revankar, C.M.; Maestas, D.C.; LaRusch, L.L.; Cimino, D.F.; Kohout, T.A.; Lefkowitz, R.J.; Prossnitz, E.R. N-Formyl Peptide Receptors Internalize but Do Not Recycle in the Absence of Arrestins. J. Biol. Chem. 2003, 278, 41581-41584. [CrossRef]

21. Luttrell, L.M.; Ferguson, S.S.G.; Daaka, Y.; Miller, W.E.; Maudsley, S.; Della Rocca, G.J.; Lin, F.-T.; Kawakatsu, H.; Owada, K.; Luttrell, D.K.; et al. $\beta$-Arrestin-Dependent Formation of $\beta 2$ Adrenergic Receptor-Src Protein Kinase Complexes. Science 1999, 283, 655-661. [CrossRef] [PubMed]

22. Luttrell, L.M.; Roudabush, F.L.; Choy, E.W.; Miller, W.E.; Field, M.E.; Pierce, K.L.; Lefkowitz, R.J. Activation and targeting of extracellular signal-regulated kinases by -arrestin scaffolds. Proc. Natl. Acad. Sci. USA 2001, 98, 2449-2454. [CrossRef] [PubMed]

23. Shenoy, S.K. Regulation of Receptor Fate by Ubiquitination of Activated beta 2-Adrenergic Receptor and beta -Arrestin. Science 2001, 294, 1307-1313. [CrossRef] [PubMed]

24. Irannejad, R.; Tsvetanova, N.G.; Lobingier, B.T.; Von Zastrow, M. Effects of endocytosis on receptor-mediated signaling. Curr. Opin. Cell Biol. 2015, 35, 137-143. [CrossRef]

25. Ferrandon, S.; Feinstein, T.N.; Castro, M.; Wang, B.; Bouley, R.; Potts, J.T.; Gardella, T.J.; Vilardaga, J.-P. Sustained cyclic AMP production by parathyroid hormone receptor endocytosis. Nat. Chem. Biol. 2009, 5, 734-742. [CrossRef]

26. Feinstein, T.N.; Yui, N.; Webber, M.J.; Wehbi, V.L.; Stevenson, H.P.; King, J.D.; Hallows, K.R.; Brown, D.; Bouley, R.; Vilardaga, J.-P. Noncanonical Control of Vasopressin Receptor Type 2 Signaling by Retromer and Arrestin. J. Biol. Chem. 2013, 288, 27849-27860. [CrossRef] 
27. Wehbi, V.L.; Stevenson, H.P.; Feinstein, T.N.; Calero, G.; Romero, G.; Vilardaga, J.-P. Noncanonical GPCR signaling arising from a PTH receptor-arrestin-G $\beta \gamma$ complex. Proc. Natl. Acad. Sci. USA 2013, 110, 1530-1535. [CrossRef]

28. Kang, J.; Shi, Y.; Xiang, B.; Qu, B.; Su, W.; Zhu, M.; Zhang, M.; Bao, G.; Wang, F.; Zhang, X.; et al. A Nuclear Function of $\beta$-Arrestin1 in GPCR Signaling: Regulation of Histone Acetylation and Gene Transcription. Cell 2005, 123, 833-847. [CrossRef]

29. Liu, S.; Luttrell, L.M.; Premont, R.T.; Rockey, D.C. $\beta$-Arrestin2 is a critical component of the GPCR-eNOS signalosome. Proc. Natl. Acad. Sci. USA 2020, 117, 11483-11492. [CrossRef]

30. Bodnar, R.J.; Yates, C.C.; Wells, A. IP-10 Blocks Vascular Endothelial Growth Factor-Induced Endothelial Cell Motility and Tube Formation via Inhibition of Calpain. Circ. Res. 2006, 98, 617-625. [CrossRef]

31. Xia, J.-B.; Mao, C.-Z.; Chen, Z.-Y.; Liu, G.-H.; Wu, H.-Y.; Zhou, D.-C.; Park, K.-S.; Zhao, H.; Kim, S.-K.; Cai, D.; et al. The CXCL10/CXCR3 axis promotes cardiac microvascular endothelial cell migration via the p38/FAK pathway in a proliferationindependent manner. Exp. Mol. Pathol. 2016, 100, 257-265. [CrossRef] [PubMed]

32. Petrai, I.; Rombouts, K.; Lasagni, L.; Annunziato, F.; Cosmi, L.; Romanelli, R.G.; Sagrinati, C.; Mazzinghi, B.; Pinzani, M.; Romagnani, S.; et al. Activation of p38MAPK mediates the angiostatic effect of the chemokine receptor CXCR3-B. Int. J. Biochem. Cell Biol. 2008, 40, 1764-1774. [CrossRef] [PubMed]

33. Smith, J.S.; Nicholson, L.T.; Suwanpradid, J.; Glenn, R.A.; Knape, N.M.; Alagesan, P.; Gundry, J.N.; Wehrman, T.S.; Atwater, A.R.; Gunn, M.D.; et al. Biased agonists of the chemokine receptor CXCR3 differentially control chemotaxis and inflammation. Sci. Signal. 2018, 11, eaaq1075. [CrossRef] [PubMed]

34. Smith, J.S.; Alagesan, P.; Desai, N.K.; Pack, T.F.; Wu, J.-H.; Inoue, A.; Freedman, N.J.; Rajagopal, S. C-X-C Motif Chemokine Receptor 3 Splice Variants Differentially Activate Beta-Arrestins to Regulate Downstream Signaling Pathways. Mol. Pharmacol. 2017, 92, 136-150. [CrossRef] [PubMed]

35. Berchiche, Y.A.; Sakmar, T.P. CXC Chemokine Receptor 3 Alternative Splice Variants Selectively Activate Different Signaling Pathways. Mol. Pharmacol. 2016, 90, 483-495. [CrossRef] [PubMed]

36. Romagnani, P.; Annunziato, F.; Lasagni, L.; Lazzeri, E.; Beltrame, C.; Francalanci, M.; Uguccioni, M.; Galli, G.; Cosmi, L.; Maurenzig, L.; et al. Cell cycle-dependent expression of CXC chemokine receptor 3 by endothelial cells mediates angiostatic activity. J. Clin. Investig. 2001, 107, 53-63. [CrossRef]

37. Lee, N.Y.; Blobe, G.C. The Interaction of Endoglin with $\beta$-Arrestin2 Regulates Transforming Growth Factor- $\beta$-mediated ERK Activation and Migration in Endothelial Cells. J. Biol. Chem. 2007, 282, 21507-21517. [CrossRef]

38. Zhang, H.; He, B. SDF1/CXCR4 axis plays a role in angiogenesis during the degeneration of intervertebral discs. Mol. Med. Rep. 2019, 20, 1203-1211. [CrossRef]

39. Mehrad, B.; Keane, M.P.; Strieter, R.M. Chemokines as mediators of angiogenesis. Thromb. Haemost. 2007, 97, 755-762. [CrossRef]

40. Cheng, Y.-H.; Eby, J.M.; Laporte, H.M.; Volkman, B.F.; Majetschak, M. Effects of cognate, non-cognate and synthetic CXCR4 and ACKR3 ligands on human lung endothelial cell barrier function. PLOS ONE 2017, 12, e0187949. [CrossRef]

41. Gao, X.; Cheng, Y.-H.; Enten, G.A.; DeSantis, A.J.; Gaponenko, V.; Majetschak, M. Regulation of the thrombin/protease-activated receptor 1 axis by chemokine (CXC motif) receptor 4. J. Biol. Chem. 2020, 295, 14893-14905. [CrossRef] [PubMed]

42. Rajagopal, S.; Kim, J.; Ahn, S.; Craig, S.; Lam, C.M.; Gerard, N.P.; Gerard, C.; Lefkowitz, R.J. Beta-arrestin- but not G proteinmediated signaling by the "decoy" receptor CXCR7. Proc. Natl. Acad. Sci. USA 2009, 107, 628-632. [CrossRef] [PubMed]

43. Zabel, B.A.; Wang, Y.; Lewén, S.; Berahovich, R.D.; Penfold, M.E.T.; Zhang, P.; Powers, J.; Summers, B.C.; Miao, Z.; Zhao, B.; et al. Elucidation of CXCR7-Mediated Signaling Events and Inhibition of CXCR4-Mediated Tumor Cell Transendothelial Migration by CXCR7 Ligands. J. Immunol. 2009, 183, 3204-3211. [CrossRef] [PubMed]

44. Cruz-Orengo, L.; Holman, D.W.; Dorsey, D.; Zhou, L.; Zhang, P.; Wright, M.; McCandless, E.E.; Patel, J.R.; Luker, G.D.; Littman, D.R.; et al. CXCR7 influences leukocyte entry into the CNS parenchyma by controlling abluminal CXCL12 abundance during autoimmunity. J. Exp. Med. 2011, 208, 327-339. [CrossRef]

45. Kim, J.; Ahn, S.; Rajagopal, K.; Lefkowitz, R.J. Independent $\beta$-Arrestin2 and Gq/Protein Kinase C $\zeta$ Pathways for ERK Stimulated by Angiotensin Type 1A Receptors in Vascular Smooth Muscle Cells Converge on Transactivation of the Epidermal Growth Factor Receptor. J. Biol. Chem. 2009, 284, 11953-11962. [CrossRef]

46. Jockers, R.; Kamal, M. Faculty Opinions recommendation of beta-Arrestin-biased agonism of the angiotensin receptor induced by mechanical stress. Faculty Opinions - Post-Publication Peer Review of the Biomedical Literature 2010, 3, 46. [CrossRef]

47. Yang, P.; Maguire, J.J.; Davenport, A.P. Apelin, Elabela/Toddler, and biased agonists as novel therapeutic agents in the cardiovascular system. Trends Pharmacol. Sci. 2015, 36, 560-567. [CrossRef]

48. Grundmann, M.; Merten, N.; Malfacini, D.; Inoue, A.; Preis, P.; Simon, K.; Rüttiger, N.; Ziegler, N.; Benkel, T.; Schmitt, N.K.; et al. Lack of beta-arrestin signaling in the absence of active $G$ proteins. Nat. Commun. 2018, 9, 1-16. [CrossRef]

49. Coureuil, M.; Lécuyer, H.; Scott, M.G.; Boularan, C.; Enslen, H.; Soyer, M.; Mikaty, G.; Bourdoulous, S.; Nassif, X.; Marullo, S. Meningococcus Hijacks a $\beta 2$-Adrenoceptor/ $\beta$-Arrestin Pathway to Cross Brain Microvasculature Endothelium. Cell 2010, 143, 1149-1160. [CrossRef]

50. Alderton, F.; Rakhit, S.; Kong, K.C.; Palmer, T.M.; Sambi, B.; Pyne, S.; Pyne, N.J. Tethering of the Platelet-derived Growth Factor $\beta$ Receptor to G-protein-coupled Receptors. J. Biol. Chem. 2001, 276, 28578-28585. [CrossRef]

51. Lee, M.-J.; Thangada, S.; Claffey, K.P.; Ancellin, N.; Liu, C.H.; Kluk, M.; Volpi, M.; Sha'Afi, R.I.; Hla, T. Vascular Endothelial Cell Adherens Junction Assembly and Morphogenesis Induced by Sphingosine-1-Phosphate. Cell 1999, 99, 301-312. [CrossRef] 
52. Kanki, H.; Sasaki, T.; Matsumura, S.; Yokawa, S.; Yukami, T.; Shimamura, M.; Sakaguchi, M.; Furuno, T.; Suzuki, T.; Mochizuki, H. $\beta$-arrestin-2 in PAR-1-biased signaling has a crucial role in endothelial function via PDGF- $\beta$ in stroke. Cell Death Dis. 2019, 10, 1-16. [CrossRef] [PubMed]

53. Rosanò, L.; Cianfrocca, R.; Masi, S.; Spinella, F.; Di Castro, V.; Biroccio, A.; Salvati, E.; Nicotra, M.R.; Natali, P.G.; Bagnato, A. $\beta$-Arrestin links endothelin A receptor to $\beta$-catenin signaling to induce ovarian cancer cell invasion and metastasis. Proc. Natl. Acad. Sci. USA 2009, 106, 2806-2811. [CrossRef] [PubMed]

54. Rosano, L.; Cianfrocca, R.; Tocci, P.; Spinella, F.; Di Castro, V.; Spadaro, F.; Salvati, E.; Biroccio, A.M.; Natali, P.G.; Bagnato, A. $\beta$-arrestin-1 is a nuclear transcriptional regulator of endothelin-1-induced $\beta$-catenin signaling. Oncogene 2013, 32, 5066-5077. [CrossRef] [PubMed]

55. Cianfrocca, R.; Rosano, L.; Spinella, F.; Di Castro, V.; Natali, P.G.; Bagnato, A. $\beta$-arrestin-1 mediates the endothelin-1-induced activation of Akt and integrin-linked kinaseThis article is one of a selection of papers published in the two-part special issue entitled 20 Years of Endothelin Research. Can. J. Physiol. Pharmacol. 2010, 88, 796-801. [CrossRef] [PubMed]

56. Cianfrocca, R.; Tocci, P.; Semprucci, E.; Spinella, F.; Di Castro, V.; Bagnato, A.; Rosano, L. $\beta$-Arrestin 1 is required for endothelin-1induced NF-KB activation in ovarian cancer cells. Life Sci. 2014, 118, 179-184. [CrossRef]

57. Narita, N.; Hanada, K.; Senoo, M.; Kato, T.; Kudo, N.; Yokono, Y.; Tsushima, M.; Toyama, Y.; Narita, M.; Tomita, H. Involvement of $\beta$-Arrestin in Endothelin Receptor Signaling: A Possible Role in the Pathogenesis of Pulmonary Arterial Hypertension. Hirosaki Igaku. 2019, 69, 146-154.

58. Goupil, E.; Fillion, D.; Clément, S.; Luo, X.; Devost, D.; Sleno, R.; Pétrin, D.; Saragovi, H.U.; Thorin, É.; Laporte, S.A.; et al. Angiotensin II Type I and Prostaglandin F2 $\alpha$ Receptors Cooperatively Modulate Signaling in Vascular Smooth Muscle Cells. J. Biol. Chem. 2015, 290, 3137-3148. [CrossRef]

59. Chun, K.-S.; Lao, H.-C.; Trempus, C.S.; Okada, M.; Langenbach, R. The prostaglandin receptor EP2 activates multiple signaling pathways and -arrestin1 complex formation during mouse skin papilloma development. Carcinogenesis 2009, 30, 1620-1627. [CrossRef]

60. Yun, S.P.; Ryu, J.M.; Jang, M.W.; Han, H.J. Interaction of profilin-1 and F-actin via a $\beta$-arrestin-1/JNK signaling pathway involved in prostaglandin E2-induced human mesenchymal stem cells migration and proliferation. J. Cell. Physiol. 2010, 226, 559-571. [CrossRef]

61. Liang, Z.; Brooks, J.; Willard, M.; Liang, K.; Yoon, Y.; Kang, S.; Shim, H. CXCR4/CXCL12 axis promotes VEGF-mediated tumor angiogenesis through Akt signaling pathway. Biochem. Biophys. Res. Commun. 2007, 359, 716-722. [CrossRef] [PubMed]

62. English, E.J.; Mahn, S.A.; Marchese, A. Endocytosis is required for CXC chemokine receptor type 4 (CXCR4)-mediated Akt activation and antiapoptotic signaling. J. Biol. Chem. 2018, 293, 11470-11480. [CrossRef] [PubMed]

63. Song, Z.-Y.; Wang, F.; Cui, S.-X.; Qu, X. Knockdown of CXCR4 Inhibits CXCL12-Induced Angiogenesis in HUVECs through Downregulation of the MAPK/ERK and PI3K/AKT and the Wnt/ $\beta$-Catenin Pathways. Cancer Investig. 2018, 36, 10-18. [CrossRef] [PubMed]

64. Luo, J.; Busillo, J.M.; Stumm, R.; Benovic, J.L. G Protein-Coupled Receptor Kinase 3 and Protein Kinase C Phosphorylate the Distal C-Terminal Tail of the Chemokine Receptor CXCR4 and Mediate Recruitment of $\beta$-Arrestin. Mol. Pharmacol. 2017, 91, 554-566. [CrossRef] [PubMed]

65. Busillo, J.M.; Armando, S.; Sengupta, R.; Meucci, O.; Bouvier, M.; Benovic, J.L. Site-specific Phosphorylation of CXCR4 Is Dynamically Regulated by Multiple Kinases and Results in Differential Modulation of CXCR4 Signaling. J. Biol. Chem. 2010, 285, 7805-7817. [CrossRef]

66. Paradis, J.S.; Ly, S.; Blondel-Tepaz, É.; Galan, J.A.; Beautrait, A.; Scott, M.G.H.; Enslen, H.; Marullo, S.; Roux, P.P.; Bouvier, M. Receptor sequestration in response to $\beta$-arrestin-2 phosphorylation by ERK1/2 governs steady-state levels of GPCR cell-surface expression. Proc. Natl. Acad. Sci. USA 2015, 112, E5160-E5168. [CrossRef]

67. Evans, A.E.; Tripathi, A.; Laporte, H.M.; Brueggemann, L.I.; Singh, A.K.; Albee, L.J.; Byron, K.L.; Tarasova, N.I.; Volkman, B.F.; Cho, T.Y.; et al. New Insights into Mechanisms and Functions of Chemokine (C-X-C Motif) Receptor 4 Heteromerization in Vascular Smooth Muscle. Int. J. Mol. Sci. 2016, 17, 971. [CrossRef]

68. Schutyser, E.; Su, Y.; Yu, Y.; Gouwy, M.; Zaja-Milatovic, S.; Van Damme, J.; Richmond, A. Hypoxia enhances CXCR4 expression in human microvascular endothelial cells and human melanoma cells. Eur. Cytokine Netw. 2007, 18, 59-70. [CrossRef]

69. Saaber, F.; Schütz, D.; Miess, E.; Abe, P.; Desikan, S.; Kumar, P.A.; Balk, S.; Huang, K.; Beaulieu, J.; Schulz, S.; et al. ACKR3 Regulation of Neuronal Migration Requires ACKR3 Phosphorylation, but Not $\beta$-Arrestin. Cell Rep. 2019, 26, 1473-1488. [CrossRef]

70. Thelen, M.; J, C.; C, G.; A, H.; M, P.; Jy, S. Faculty Opinions recommendation of Biased signaling at chemokine receptors. Faculty Opinions - Post-Publication Peer Review of the Biomedical Literature 2018, 290, 9542-9554. [CrossRef]

71. Montpas, N.; St-Onge, G.; Nama, N.; Rhainds, D.; Benredjem, B.; Girard, M.; Hickson, G.; Pons, V.; Heveker, N. Ligand-specific conformational transitions and intracellular transport are required for atypical chemokine receptor 3-mediated chemokine scavenging. J. Biol. Chem. 2018, 293, 893-905. [CrossRef] [PubMed]

72. Zhang, M.; Qiu, L.; Zhang, Y.; Xu, D.; Zheng, J.C.; Jiang, L. CXCL12 enhances angiogenesis through CXCR7 activation in human umbilical vein endothelial cells. Sci. Rep. 2017, 7, 1-9. [CrossRef] [PubMed]

73. Werner, L.; Elad, H.; Brazowski, E.; Tulchinsky, H.; Vigodman, S.; Kopylov, U.; Halpern, Z.; Guzner-Gur, H.; Dotan, I. Reciprocal regulation of CXCR4 and CXCR7 in intestinal mucosal homeostasis and inflammatory bowel disease. J. Leukoc. Biol. 2011, 90, 583-590. [CrossRef] 
74. Maksym, R.B.; Tarnowski, M.; Grymula, K.; Tarnowska, J.; Wysoczynski, M.; Liu, R.; Czerny, B.; Ratajczak, J.; Kucia, M.; Ratajczak, J. The role of stromal-derived factor-1 - CXCR7 axis in development and cancer. Eur. J. Pharmacol. 2009, 625, 31-40. [CrossRef]

75. Wingler, L.M.; Elgeti, M.; Hilger, D.; Latorraca, N.R.; Lerch, M.T.; Staus, D.P.; O Dror, R.; Kobilka, B.K.; Hubbell, W.L.; Lefkowitz, R.J. Angiotensin Analogs with Divergent Bias Stabilize Distinct Receptor Conformations. Cell 2019, 176, 468-478.e11. [CrossRef] [PubMed]

76. Kang, Y.; Kim, J.; Anderson, J.P.; Wu, J.; Gleim, S.R.; Kundu, R.K.; McLean, D.L.; Kim, J.-D.; Park, H.; Jin, S.-W.; et al. Apelin-APJ signaling is a critical regulator of endothelial MEF2 activation in cardiovascular development. Circ. Res. 2013, 113, 22-31. [CrossRef]

77. Grisanti, L.A.; Schumacher, S.M.; Tilley, D.G.; Koch, W.J. Designer Approaches for G Protein-Coupled Receptor Modulation for Cardiovascular Disease. JACC: Basic Transl. Sci. 2018, 3, 550-562. [CrossRef]

78. Liu, J.J.; Horst, R.; Katritch, V.; Stevens, R.C.; Wüthrich, K. Biased Signaling Pathways in 2-Adrenergic Receptor Characterized by 19F-NMR. Science 2012, 335, 1106-1110. [CrossRef]

79. Nobles, K.N.; Xiao, K.; Ahn, S.; Shukla, A.K.; Lam, C.M.; Rajagopal, S.; Strachan, R.T.; Huang, T.-Y.; Bressler, E.A.; Hara, M.R.; et al. Distinct Phosphorylation Sites on the 2-Adrenergic Receptor Establish a Barcode That Encodes Differential Functions of -Arrestin. Sci. Signal. 2011, 4, ra51. [CrossRef]

80. Lee, M.-J.; Van Brocklyn, J.R.; Thangada, S.; Liu, C.H.; Hand, A.R.; Menzeleev, R.; Spiegel, S.; Hla, T. Sphingosine-1-Phosphate as a Ligand for the G Protein-Coupled Receptor EDG-1. Science 1998, 279, 1552-1555. [CrossRef]

81. Van Brocklyn, J.R.; Lee, M.-J.; Menzeleev, R.; Olivera, A.; Edsall, L.C.; Cuvillier, O.; Thomas, D.M.; Coopman, P.J.; Thangada, S.; Liu, C.H.; et al. Dual Actions of Sphingosine-1-Phosphate: Extracellular through the Gi-coupled Receptor Edg-1 and Intracellular to Regulate Proliferation and Survival. J. Cell Biol. 1998, 142, 229-240. [CrossRef] [PubMed]

82. Hla, T.; Maciag, T. An abundant transcript induced in differentiating human endothelial cells encodes a polypeptide with structural similarities to G-protein-coupled receptors. J. Biol. Chem. 1990, 265, 9308-9313. [PubMed]

83. Hornuss, C.; Hammermann, R.; Fuhrmann, M.; Juergens, U.; Racké, K. Human and rat alveolar macrophages express multiple EDG receptors. Eur. J. Pharmacol. 2001, 429, 303-308. [CrossRef]

84. Mazurais, D.; Robert, P.; Gout, B.; Berrebi-Bertrand, I.; Laville, M.P.; Calmels, T. Cell Type-specific Localization of Human Cardiac S1P Receptors. J. Histochem. Cytochem. 2002, 50, 661-669. [CrossRef] [PubMed]

85. Jin, Y.; Knudsen, E.; Wang, L.; Bryceson, Y.T.; Damaj, B.; Gessani, S.; Maghazachi, A.A.; Maghazachi, A.A. Sphingosine 1-phosphate is a novel inhibitor of T-cell proliferation. Blood 2003, 101, 4909-4915. [CrossRef]

86. Lee, M.J.; Evans, M.; Hla, T. The inducible G protein-coupled receptor edg-1 signals via the G(i)/mitogen-activated protein kinase pathway. J. Biol. Chem. 1996, 271, 11272-11279. [CrossRef]

87. Windh, R.T.; Lee, M.-J.; Hla, T.; An, S.; Barr, A.J.; Manning, D.R. Differential Coupling of the Sphingosine 1-Phosphate Receptors Edg-1, Edg-3, and H218/Edg-5 to the Gi, Gq, and G12Families of Heterotrimeric G Proteins. J. Biol. Chem. 1999, $274,27351-27358$. [CrossRef]

88. Poirier, B.; Briand, V.; Kadereit, D.; Schäfer, M.; Wohlfart, P.; Philippo, M.-C.; Caillaud, D.; Gouraud, L.; Grailhe, P.; Bidouard, J.P.; et al. A G protein-biased S1P1 agonist, SAR247799, protects endothelial cells without affecting lymphocyte numbers. Sci. Signal. 2020, 13, eaax8050. [CrossRef]

89. Oo, M.L.; Chang, S.-H.; Thangada, S.; Wu, M.-T.; Rezaul, K.; Blaho, V.; Hwang, S.-I.; Han, D.K.; Hla, T. Engagement of S1P1-degradative mechanisms leads to vascular leak in mice. J. Clin. Investig. 2011, 121, 2290-2300. [CrossRef]

90. Shea, B.S.; Brooks, S.F.; Fontaine, B.A.; Chun, J.; Luster, A.D.; Tager, A.M. Prolonged Exposure to Sphingosine 1-Phosphate Receptor-1 Agonists Exacerbates Vascular Leak, Fibrosis, and Mortality after Lung Injury. Am. J. Respir. Cell Mol. Biol. 2010, 43, 662-673. [CrossRef]

91. Coughlin, S.R. Thrombin signalling and protease-activated receptors. Nat. Cell Biol. 2000, 407, 258-264. [CrossRef] [PubMed]

92. Riewald, M.; Petrovan, R.J.; Donner, A.; Ruf, W. Activated protein C signals through the thrombin receptor PAR1 in endothelial cells. J. Endotoxin Res. 2003, 9, 317-321. [CrossRef] [PubMed]

93. Ludeman, M.J.; Kataoka, H.; Srinivasan, Y.; Esmon, N.L.; Esmon, C.T.; Coughlin, S.R. PAR1 Cleavage and Signaling in Response to Activated Protein C and Thrombin. J. Biol. Chem. 2005, 280, 13122-13128. [CrossRef] [PubMed]

94. Mosnier, L.O.; Sinha, R.K.; Burnier, L.; Bouwens, E.A.; Griffin, J.H. Biased agonism of protease-activated receptor 1 by activated protein C caused by noncanonical cleavage at Arg46. Blood 2012, 120, 5237-5246. [CrossRef] [PubMed]

95. Roy, R.V.; Ardeshirylajimi, A.; Dinarvand, P.; Yang, L.; Rezaie, A.R. Occupancy of human EPCR by protein C induces $\beta$-arrestin-2 biased PAR1 signaling by both APC and thrombin. Blood 2016, 128, 1884-1893. [CrossRef]

96. Willis-Fox, O.; Preston, R.J.S. Molecular basis of protease-activated receptor 1 signaling diversity. J. Thromb. Haemost. 2019, 18, 6-16. [CrossRef]

97. Yanagisawa, M.; Kurihara, H.; Kimura, S.; Tomobe, Y.; Kobayashi, M.; Mitsui, Y.; Yazaki, Y.; Goto, K.; Masaki, T. A novel potent vasoconstrictor peptide produced by vascular endothelial cells. Nat. Cell Biol. 1988, 332, 411-415. [CrossRef]

98. Davenport, A.P.; Hyndman, K.A.; Dhaun, N.; Southan, C.; Kohan, D.E.; Pollock, J.S.; Pollock, D.M.; Webb, D.J.; Maguire, J.J. Endothelin. Pharmacol. Rev. 2016, 68, 357-418. [CrossRef]

99. Gärtner, F.; Seidel, T.; Schulz, U.; Gummert, J.; Milting, H. Desensitization and Internalization of Endothelin Receptor A. J. Biol. Chem. 2013, 288, 32138-32148. [CrossRef] 
100. Angers, S.; Salahpour, A.; Bouvier, M. DIMERIZATION: An Emerging Concept for G Protein-Coupled Receptor Ontogeny and Function. Annu. Rev. Pharmacol. Toxicol. 2002, 42, 409-435. [CrossRef]

101. Gurevich, V.V.; Gurevich, E.V. Arrestins: Critical Players in Trafficking of Many GPCRs. In Progress in Molecular Biology and Translational Science; Elsevier: Amsterdam, The Netherlands, 2015; Volume 132, pp. 1-14.

102. Fillion, D.; Devost, D.; Sleno, R.; Inoue, A.; Hébert, T.E. Asymmetric Recruitment of $\beta$-Arrestin $1 / 2$ by the Angiotensin II Type I and Prostaglandin F2 $\alpha$ Receptor Dimer. Front. Endocrinol. 2019, 10. [CrossRef] [PubMed]

103. Konya, V.; Marsche, G.; Schuligoi, R.; Heinemann, A. E-type prostanoid receptor 4 (EP4) in disease and therapy. Pharmacol. Ther. 2013, 138, 485-502. [CrossRef] [PubMed]

104. Olsson, A.-K.; Dimberg, A.; Kreuger, J.; Claesson-Welsh, L. VEGF receptor signalling ? in control of vascular function. Nat. Rev. Mol. Cell Biol. 2006, 7, 359-371. [CrossRef] [PubMed]

105. Coso, S.; Bovay, E.; Petrova, T.V. Pressing the right buttons: signaling in lymphangiogenesis. Blood 2014, 123, 2614-2624. [CrossRef] [PubMed]

106. Wirzenius, M.; Tammela, T.; Uutela, M.; He, Y.; Odorisio, T.; Zambruno, G.; Nagy, J.A.; Dvorak, H.F.; Ylaä-Herttuala, S.; Shibuya, M.; et al. Distinct vascular endothelial growth factor signals for lymphatic vessel enlargement and sprouting. J. Exp. Med. 2007, 204, 1431-1440. [CrossRef]

107. Gavard, J.; Gutkind, J.S. VEGF controls endothelial-cell permeability by promoting the $\beta$-arrestin-dependent endocytosis of VE-cadherin. Nat. Cell Biol. 2006, 8, 1223-1234. [CrossRef]

108. Мa, Z.; Yu, Y.-R.; Badea, C.T.; Kovacs, J.J.; Xiong, X.; Comhair, S.; Piantadosi, C.A.; Rajagopal, S. Vascular Endothelial Growth Factor Receptor 3 Regulates Endothelial Function Through $\beta$-Arrestin 1. Circulation 2019, 139, 1629-1642. [CrossRef]

109. Noma, T.; Lemaire, A.; Prasad, S.V.N.; Barki-Harrington, L.; Tilley, D.G.; Chen, J.; Le Corvoisier, P.; Violin, J.D.; Wei, H.; Lefkowitz, R.J.; et al. $\beta$-Arrestin-mediated $\beta 1$-adrenergic receptor transactivation of the EGFR confers cardioprotection. J. Clin. Investig. 2007, 117, 2445-2458. [CrossRef]

110. Costello, C.M.; Mccullagh, B.; Howell, K.; Sands, M.; Belperio, J.A.; Keane, M.P.; Gaine, S.; McLoughlin, P. A role for the CXCL12 receptor, CXCR7, in the pathogenesis of human pulmonary vascular disease. Eur. Respir. J. 2011, 39, 1415-1424. [CrossRef]

111. Kovacs, J.J.; Hara, M.R.; Davenport, C.L.; Kim, J.; Lefkowitz, R.J. Arrestin Development: Emerging Roles for $\beta$-arrestins in Developmental Signaling Pathways. Dev. Cell 2009, 17, 443-458. [CrossRef]

112. Rajagopal, S.; Kovacs, J.; Badea, C.T.; Johnson, G.A.; Rockman, H.A.; Piantadosi, C.A.; Lefkowitz, R.J. Beta-arrestins Regulate Signaling by Bone Morphogenetic Protein Type II Receptor in Pulmonary Arterial Hypertension. J. Am. Coll. Cardiol. 2011, 57, E2046. [CrossRef]

113. Cai, J.; Pardali, E.; Sanchez-Duffhues, G.; Dijke, P.T. BMP signaling in vascular diseases. FEBS Lett. 2012, 586, 1993-2002. [CrossRef]

114. Morrell, N.W. Pulmonary Hypertension Due to BMPR2 Mutation: A New Paradigm for Tissue Remodeling? Proc. Am. Thorac. Soc. 2006, 3, 680-686. [CrossRef] [PubMed]

115. Lerman, A.; Zeiher, A.M. Endothelial Function. Circulation 2005, 111, 363-368. [CrossRef] [PubMed]

116. Budhiraja, R.; Tuder, R.M.; Hassoun, P.M. Endothelial Dysfunction in Pulmonary Hypertension. Circulation 2004, $109,159-165$. [CrossRef] [PubMed]

117. Farkas, D.; Kraskauskas, D.; Drake, J.I.; Alhussaini, A.A.; Kraskauskiene, V.; Bogaard, H.J.; Cool, C.D.; Voelkel, N.F.; Farkas, L. CXCR4 Inhibition Ameliorates Severe Obliterative Pulmonary Hypertension and Accumulation of C-Kit+ Cells in Rats. PloS ONE 2014, 9, e89810. [CrossRef]

118. Shen, C.-C.; Chen, B.; Gu, J.; Ning, J.-L.; Zeng, J.; Yi, B.; Lu, K. AMD3100 treatment attenuates pulmonary angiogenesis by reducing the c-kit $(+)$ cells and its pro-angiogenic activity in CBDL rat lungs. Biochim. Biophys. Acta 2018, 1864, 676-684. [CrossRef]

119. Hao, H.; Hu, S.; Chen, H.; Bu, D.; Zhu, L.; Xu, C.; Chu, F.; Huo, X.; Tang, Y.; Sun, X.; et al. Loss of Endothelial CXCR7 Impairs Vascular Homeostasis and Cardiac Remodeling After Myocardial Infarction. Circulation 2017, 135, 1253-1264. [CrossRef]

120. Chen, B.; Soto, A.G.; Coronel, L.J.; Goss, A.; Van Ryn, J.; Trejo, J. Characterization of Thrombin-Bound Dabigatran Effects on Protease-Activated Receptor-1 Expression and Signaling In Vitro. Mol. Pharmacol. 2015, 88, 95-105. [CrossRef]

121. Griffin, J.H.; Zlokovic, B.V.; Mosnier, L.O. Activated protein C: biased for translation. Blood 2015, 125, 2898-2907. [CrossRef]

122. Desai, A.; A DeSouza, S. Treatment of pulmonary hypertension with left heart disease: a concise review. Vasc. Heal. Risk Manag. 2017, 13, 415-420. [CrossRef] [PubMed]

123. Folkman, J.; Merler, E.; Abernathy, C.; Williams, G. ISOLATION OF A TUMOR FACTOR RESPONSIBLE FOR ANGIOGENESIS. J. Exp. Med. 1971, 133, 275-288. [CrossRef]

124. Shenoy, S.K.; Han, S.-O.; Zhao, Y.L.; Hara, M.R.; Oliver, T.; Cao, Y.; Dewhirst, M.W. $\beta$-arrestin1 mediates metastatic growth of breast cancer cells by facilitating HIF-1-dependent VEGF expression. Oncogene 2011, 31, 282-292. [CrossRef] [PubMed]

125. Smith, N.R.; Baker, D.; James, N.H.; Ratcliffe, K.; Jenkins, M.; Ashton, S.E.; Sproat, G.; Swann, R.; Gray, N.; Ryan, A.; et al. Vascular Endothelial Growth Factor Receptors VEGFR-2 and VEGFR-3 Are Localized Primarily to the Vasculature in Human Primary Solid Cancers. Clin. Cancer Res. 2010, 16, 3548-3561. [CrossRef] [PubMed]

126. Benedito, R.; Rocha, S.F.; Woeste, M.; Zamykal, M.; Radtke, F.; Casanovas, O.; Duarte, A.; Pytowski, B.; Adams, R.H. Notchdependent VEGFR3 upregulation allows angiogenesis without VEGF-VEGFR2 signalling. Nat. Cell Biol. 2012, 484, 110-114. [CrossRef] [PubMed] 
127. Taraseviciene-Stewart, L.; Kasahara, Y.; Alger, L.; Hirth, P.; Mc Mahon, G.; Waltenberger, J.; Voelkel, N.F.; Tuder, R.M. Inhibition of the VEGF receptor 2 combined with chronic hypoxia causes cell death-dependent pulmonary endothelial cell proliferation and severe pulmonary hypertension. FASEB J. 2001, 15, 427-438. [CrossRef] [PubMed]

128. Hwangbo, C.; Lee, H.-W.; Kang, H.; Ju, H.; Wiley, D.S.; Papangeli, I.; Han, J.; Kim, J.-D.; Dunworth, W.P.; Hu, X.; et al. Modulation of Endothelial Bone Morphogenetic Protein Receptor Type 2 Activity by Vascular Endothelial Growth Factor Receptor 3 in Pulmonary Arterial Hypertension. Circulation 2017, 135, 2288-2298. [CrossRef] 